\title{
Highly Selective and Tunable Protein Hydrolysis by a Polyoxometalate Complex in Surfactant Solutions: A Step toward the Development of Artificial Metalloproteases for Membrane Proteins
}

\author{
Annelies Sap, ${ }^{\dagger}$ Laurens Vandebroek, ${ }^{\dagger}$ Vincent Goovaerts, $^{\dagger}$ Erik Martens, ${ }^{\ddagger}$ Paul Proost, ${ }^{\ddagger}$ \\ and Tatjana N. Parac-Vogt*,† \\ ${ }^{\dagger}$ Department of Chemistry, KU Leuven, Celestijnenlaan 200F, Box 2404, 3001 Leuven, Belgium \\ ${ }^{\ddagger}$ Department of Microbiology and Immunology, KU Leuven, Herestraat 49, Box 1042, 3000 Leuven, Belgium
}

\section{Supporting Information}

\begin{abstract}
This study represents the first example of protein hydrolysis at $\mathrm{pH}=7.4$ and $60{ }^{\circ} \mathrm{C}$ by a metalsubstituted polyoxometalate (POM) in the presence of a zwitterionic surfactant. Edman degradation results show that in the presence of $0.5 \% \mathrm{w} / \mathrm{v}$ 3-[(3-cholamidopropyl)dimethylammonio]-1-propanesulfonate (CHAPS) detergent, a $\mathrm{Zr}(\mathrm{IV})$-substituted Wells-Dawson-type POM, $\mathrm{K}_{15} \mathrm{H}\left[\mathrm{Zr}\left(\alpha_{2}\right.\right.$ $\left.\left.\mathrm{P}_{2} \mathrm{~W}_{17} \mathrm{O}_{61}\right)_{2}\right] \cdot 25 \mathrm{H}_{2} \mathrm{O}$ (Zr1-WD2), selectively hydrolyzes human serum albumin exclusively at peptide bonds involving Asp or Glu residues, which contain carboxyl groups in their side chains. The selectivity and extent of protein cleavage are tuned by the CHAPS surfactant by an unfolding mechanism that provides POM access to the hydrolyzed peptide bonds.
\end{abstract}

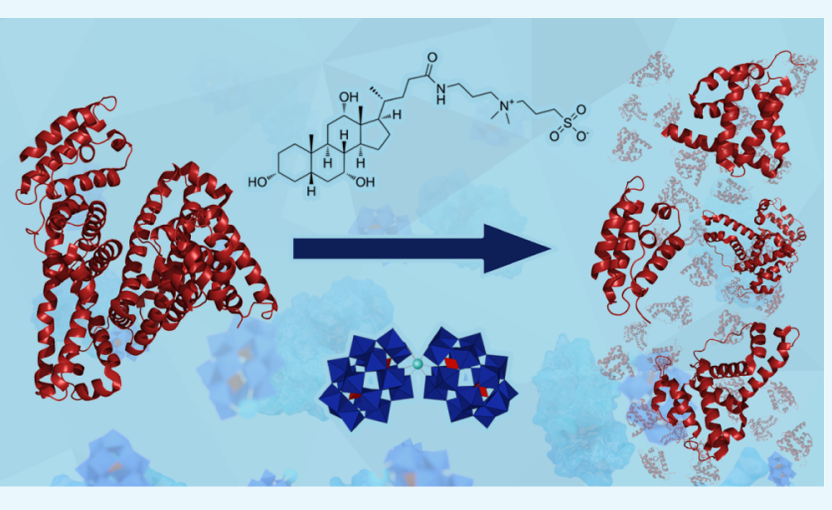

\section{INTRODUCTION}

On the basis of complete sequencing of several genomes, $30 \%$ of all proteins are estimated to be hydrophobic membrane proteins. ${ }^{1,2}$ The study of the structure and function of this large class of proteins is essential as they are among the prime drug targets. In fact, $60 \%$ of the current drug targets are located on the cell surface. ${ }^{3}$ The large size, structural complexity, and intrinsic hydrophobicity of these biomolecules often complicate their structural investigations by the existing experimental methods. Therefore, controlled fragmentation of membrane proteins into smaller fragments remains a key approach to facilitate their structural analysis. ${ }^{4}$ However, this requires the hydrolysis of the peptide bond, which has an estimated half-life of between 350 and 600 years under physiological conditions. $^{5-7}$ In addition, as a result of their hydrophobic nature, membrane proteins are insoluble in aqueous solutions, and denaturation is often encountered. Therefore, the addition of surfactants is often essential to mimic a hydrophobic environment and stimulate solubilization of membrane proteins. Generally, the concentration of the surfactant should be maintained above the critical micelle concentration (CMC), ${ }^{8}$ and therefore, relatively high surfactant concentrations (usually in the range of $0.5-1.0 \% \mathrm{w} / \mathrm{v}$ ) are required. ${ }^{9}$

Proteolytic enzymes are often used to hydrolyze peptide bonds in proteins for many purposes in biochemistry, biotechnology, and proteomics. However, they are very sensitive to the experimental conditions and often undergo denaturation in the presence of surfactants, which results in the loss of catalytic activity. Therefore, they are not suitable for the hydrolysis of hydrophobic and membrane proteins. Consequently, there is an urgent need for new synthetic proteases that are compatible with surfactants and can eventually be used to hydrolyze membrane proteins in an efficient and selective manner under mild reaction conditions.

Several metal complexes have been shown to induce hydrolysis of peptide bonds in proteins; ${ }^{10-16}$ however, their catalytic ability under the conditions pertinent to membrane proteins has been largely unexplored. $\mathrm{Pd}^{\mathrm{II}}$ and $\mathrm{Pt}^{\mathrm{II}}$ complexes have been studied for the selective hydrolysis of proteins in solutions containing surfactants; 9,16 however, very low $\mathrm{pH}$ conditions $(2.5-2.9)$ were required to observe the reactivity, which is disadvantageous as this often leads to pronounced background cleavage and also results in denaturation of the protein under study. More recently, a $\mathrm{Ni}(\mathrm{II})$-containing complex has been shown to cleave a terminal affinity tag from a recombinant fusion protein, thus providing an interesting alternative for currently used techniques. ${ }^{17}$

Polyoxometalates (POMs) are a class of inorganic metaloxygen clusters with a range of tunable properties. ${ }^{18-20}$ POMs are commercially used as catalysts in a wide range of chemical reactions. ${ }^{21-24}$ Moreover, the biological activity of POMs has been reported with respect to their antiviral, antibacterial, and

Received: February 13, 2017

Accepted: April 28, 2017

Published: May 11, 2017 


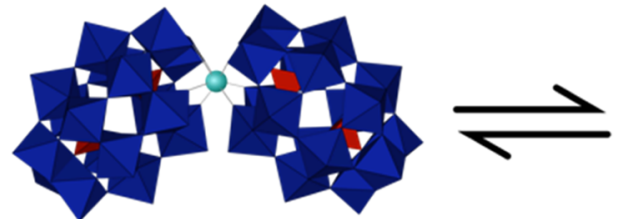

A

$1: 2$

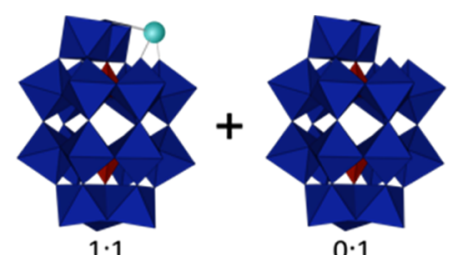

1:1

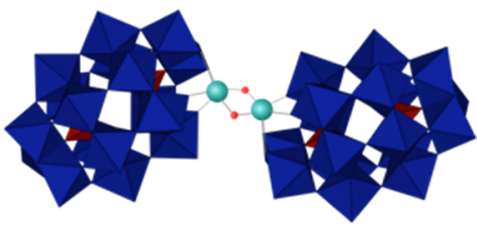

$2: 2$

B

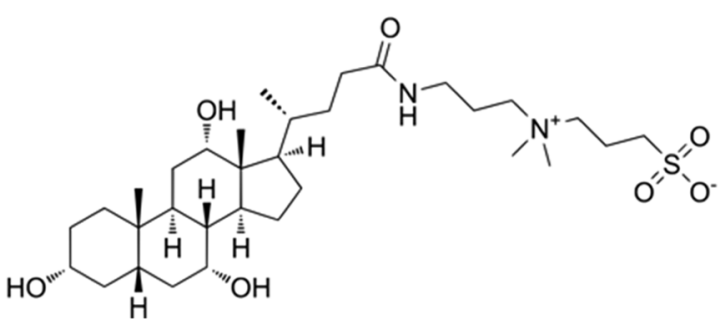

Figure 1. (a) Equilibria between the 1:2, 1:1, and 2:2 species of the $\mathrm{Zr}(\mathrm{IV})$-substituted Wells-Dawson POM. WO $\mathrm{W}_{6}$ octahedrons are represented in blue, $\mathrm{PO}_{4}$ tetrahedrons in red, and $\mathrm{Zr}(\mathrm{IV})$ in green. (b) Chemical structure of the zwitterionic surfactant, CHAPS.

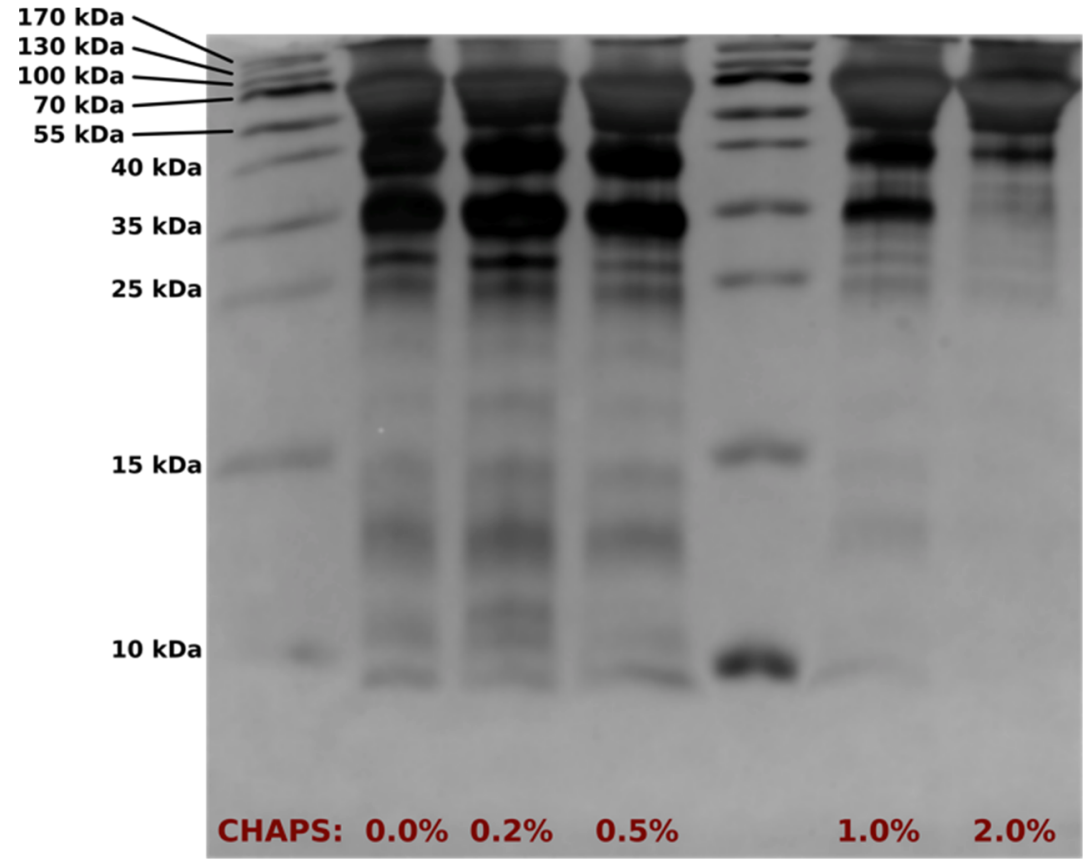

Figure 2. Silver-stained sodium dodecyl sulfate polyacrylamide gel electrophoresis (SDS-PAGE) gels of HSA hydrolysis by Zr1-WD2 POM in phosphate buffer $(10 \mathrm{mM}, \mathrm{pH} 7.4)$ at $60{ }^{\circ} \mathrm{C}$ in the absence and presence of surfactants: Influence of increasing \% w/v CHAPS after 2 days of incubation. From left to right: protein ladder; 0.0, 0.2, 0.5\% CHAPS; protein ladder; 1.0, 2.0\% CHAPS.

anticancer properties. ${ }^{25-28}$ We have recently demonstrated that POMs exhibit reactivity toward a range of biologically relevant molecules and their model systems. ${ }^{29-34}$ Recently, the ability of metal-substituted POMs to act as a novel class of artificial peptidases has been introduced by our group. $\mathrm{Zr}(\mathrm{IV})$ substituted POMs have been proven to selectively cleave proteins, ranging from a small, flexible polypeptide system, such as oxidized insulin chain $\mathrm{B},{ }^{35}$ to larger protein systems with a defined tertiary structure and surface charge, such as hen egg white lysozyme (HEWL), ${ }^{36}$ human serum albumin (HSA), ${ }^{37,38}$ myoglobin, ${ }^{39}$ and cytochrome c. ${ }^{40}$ The hydrolytic experiments were performed in aqueous solutions under physiological $\mathrm{pH}$ conditions; however, to develop $\mathrm{Zr}(\mathrm{IV})$-substituted POMs as artificial proteases for hydrophobic proteins, their activity as catalysts in the presence of surfactants needs to be established. We recently demonstrated that in the presence of anionic, 


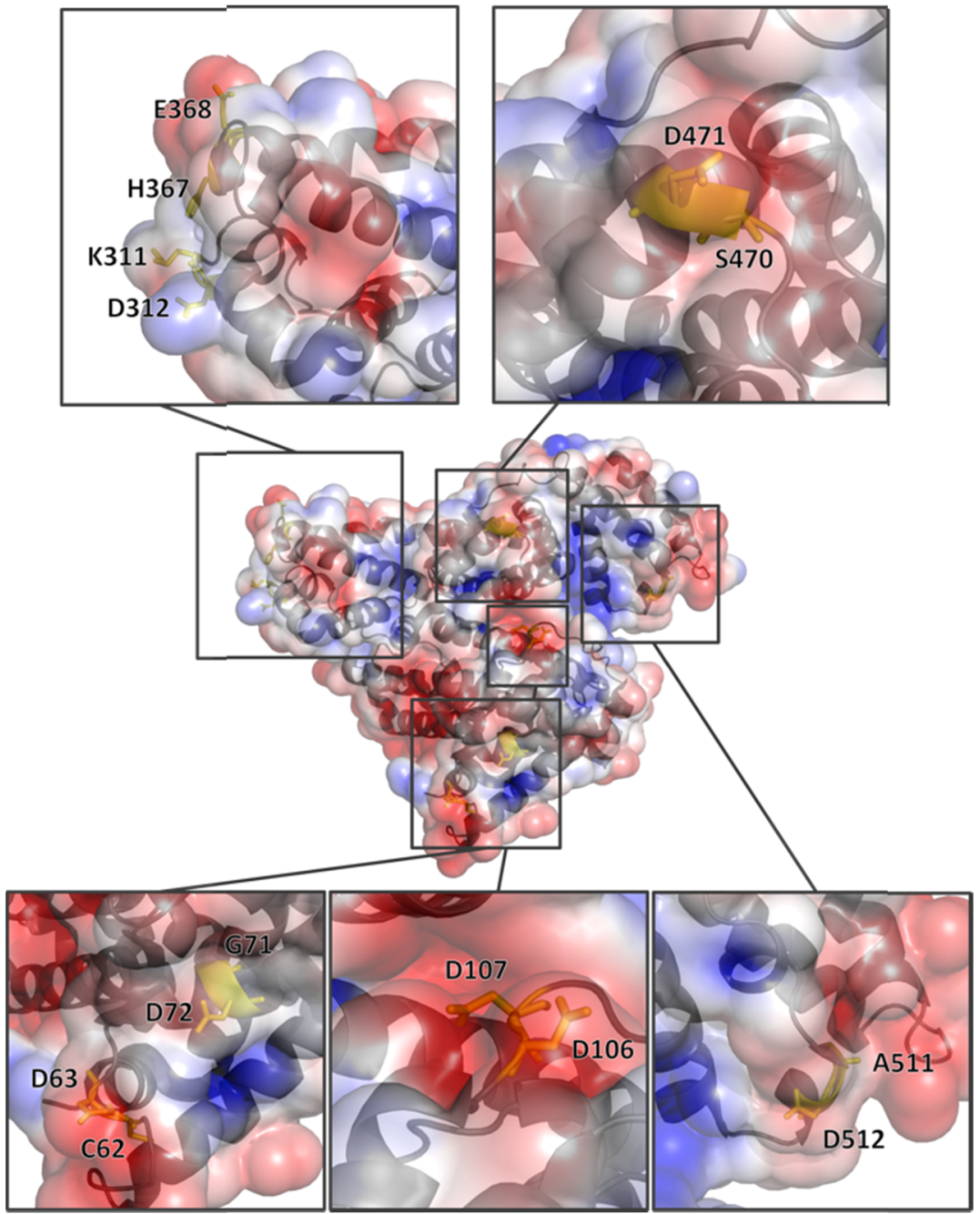

Figure 3. 3D structure and surface charge distribution. Negatively charged surface areas are shown in red, and positively charged surface areas are shown in blue. Asp residues in Asp-X bonds that are hydrolyzed are shown in yellow. The image was created using PyMol molecular visualization system software.

neutral, and zwitterionic surfactants, the $\mathrm{Zr}(\mathrm{IV})$-substituted Wells-Dawson POM, $\mathrm{K}_{15} \mathrm{H}\left[\mathrm{Zr}\left(\alpha_{2}-\mathrm{P}_{2} \mathrm{~W}_{17} \mathrm{O}_{61}\right)_{2}\right]$ (1), preserves its catalytic activity toward hydrolysis of the peptide bond in dipeptides. ${ }^{41}$ Diffusion Ordered NMR Spectroscopy (DOSY) has shown that anionic and neutral surfactants do not exhibit any interaction with $\mathbf{1}$, whereas a tertiary system is formed between the dipeptide, POM, and the surfactant in the presence of zwitterionic surfactants such as 3-[(3cholamidopropyl)dimethylammonio]-1-propanesulfonate (CHAPS). The interaction between 1 and CHAPS occurs through the positively charged ammonium group, whereas, at the same time, the negative charge of the sulfonate group attenuates this electrostatic interaction. Thereby, precipitation that typically occurs in the presence of positively charged surfactants is prevented. ${ }^{41,42}$ However, the applicability of $\mathrm{Zr}(\mathrm{IV})$-substituted POMs toward protein hydrolysis in surfactant solutions is challenging because interactions between the POM and the surfactant may shield POM binding to the protein, which is largely electrostatic in nature. Moreover, the partial unfolding of the protein caused by surfactants may affect the selectivity of protein hydrolysis by altering $\mathrm{POM} /$ protein interactions, which are proposed to occur according to the lock and key principle. ${ }^{25,43}$ Therefore, in this study, we explore the compatibility of $\mathbf{1}$ to act as a metalloprotease for the hydrolysis of HSA in the presence of the zwitterionic surfactant, CHAPS (see Figure 1), which is widely used for solubilizing membrane proteins. ${ }^{44,45}$ HSA consists of 585 amino acids and serves as an excellent model for studying the hydrolytic activity of Zr-POMs in surfactant solutions. The protein has been structurally well characterized, and its hydrolysis by the Zr-POMs has been studied in detail. This offers the possibility to elucidate the role of the detergents in the activity and selectivity of the catalyst.

\section{RESULTS AND DISCUSSION}

In the hydrolysis experiments, HSA $(0.02 \mathrm{mM})$ was incubated with 1 in phosphate buffer $(10 \mathrm{mM}, \mathrm{pH} 7.4)$ at $60{ }^{\circ} \mathrm{C}$ in the presence of different concentrations of CHAPS $(0.0-2.0 \% \mathrm{w} /$ $\mathrm{v})$. To monitor the progress of the reaction, aliquots of the homogeneous reaction mixture were first taken at different time intervals. Then, the polypeptide fragments that were formed as a result of protein hydrolysis were separated by SDS-PAGE. The presence of multiple bands on SDS-PAGE (see Figure 2) clearly indicate that $\mathbf{1}$ is able to hydrolyze HSA in the presence of up to $2.0 \% \mathrm{w} / \mathrm{v}$ CHAPS, which is well above its CMC (0.5\% $\mathrm{w} / \mathrm{v})$ and above the range of surfactant concentrations that are typically used for solubilization of membrane proteins (0.5- 
$1.0 \% \mathrm{w} / \mathrm{v}){ }^{9}$ Interestingly, an increase in CHAPS concentration led to a gradual decrease in the number and intensity of the bands in SDS-PAGE. Longer incubation times resulted in more intense bands, which is consistent with the increasing yields of protein fragmentation (see Figure S1). Our previous studies have shown that no hydrolysis of HSA was observed in the absence of the Zr-POMs. ${ }^{37,38}$ In the presence of the lacunary Wells-Dawson $\mathrm{K}_{10}\left[\alpha_{2}-\mathrm{P}_{2} \mathrm{~W}_{17} \mathrm{O}_{61}\right] \cdot 20 \mathrm{H}_{2} \mathrm{O}$ POM, no hydrolysis was observed either, indicating that the presence of $\mathrm{Zr}(\mathrm{IV})$ is essential for the hydrolytic activity. Moreover, when the $\mathrm{ZrCl}_{4}$ salt was used, limited hydrolysis yields and the formation of insoluble $\mathrm{Zr}(\mathrm{IV})$ gels were observed, emphasizing the need of the $\mathrm{POM}$ as a $\mathrm{Zr}(\mathrm{IV})$-stabilizing and protein-recognizing ligand.

Edman degradation of polypeptide fragments observed in SDS-PAGE unambiguously confirmed that, in the presence of $0.5 \%$ CHAPS, HSA was hydrolyzed by 1 at seven distinct sites: Cys62-Asp63, Gly71-Asp72, Asp107-Asp108, Lys313Asp314, His367-Glu368, Ser470-Asp471, and Ala511Asp512 visible on the gel (see Figures S2 and S3 and Table S1). Remarkably, all of the hydrolyzed peptide bonds in HSA were upstream from either the Asp or the Glu amino acid, both of which contain a carboxyl group in their side chains. This is in full accordance with our previous findings, which showed that, in the absence of surfactants, proteins were mainly hydrolyzed next to Asp or Glu residues that were located in the positive patches of proteins. The high selectivity of $\mathrm{Zr}(\mathrm{IV})$ toward hydrolyzing peptide bonds that involve Asp and Glu residues can be rationalized by two explanations: (i) the anchoring of the carboxyl group side chain to $\mathrm{Zr}(\mathrm{IV})$, or (ii) by the ability of the deprotonated carboxyl group to accept a proton from the coordinated water molecule, making it a more effective nucleophile. ${ }^{46}$ Interestingly, CHAPS plays a significant role in tuning the reactivity and selectivity of 1 toward HSA hydrolysis. In the absence of CHAPS, the cleavage was observed at four peptide bonds (Arg114-Leu115, Ala257-Asp258, Lys313Asp314, Cys302-Glu303), whereas seven cleavage sites were observed in the presence of CHAPS. Interestingly, all cleaved peptide bonds are located in the vicinity of a positively charged surface patch that can electrostatically interact with the negatively charged POM surface (Figure 3 ). With the exception of the hydrolysis site, Lys313-Asp314, which is observed both in the absence of CHAPS and in the presence of $0.5 \%$ CHAPS, the surfactant is clearly responsible for altering the selectivity and generating an increase in the number of cleavage sites. Surfactants are known to break noncovalent interactions in proteins, ${ }^{47}$ and it is likely that this results in the opening of the three-dimensional (3D) structure of HSA, making the potential $\mathrm{X}$-Asp cleavage sites more accessible for hydrolysis.

Circular dichroism (CD) measurements shown in Figure 4 show a clear indication that CHAPS interacts with HSA in such a way that the $\alpha$-helical content of HSA gradually lowers from $1.0 \%$ CHAPS onward, indicating a partial unfolding of the protein. In addition, Figure S5 shows that, under a constant CHAPS concentration and increasing concentrations of 1 , a slight decrease in $\alpha$-helix takes place, indicating that interactions between 1 and HSA take place in the surfactant solution.

It has been known that $\mathbf{1}$ undergoes equilibria in solution and that different species can be present depending on the experimental conditions, such as concentration, $\mathrm{pH}$, temperature, or incubation time. The monomeric 1:1 species, which is presumed to be the catalytically active species, is a very elusive species due to the fast equilibria between the different POMs (see Figure 1). However, we were recently able to isolate a

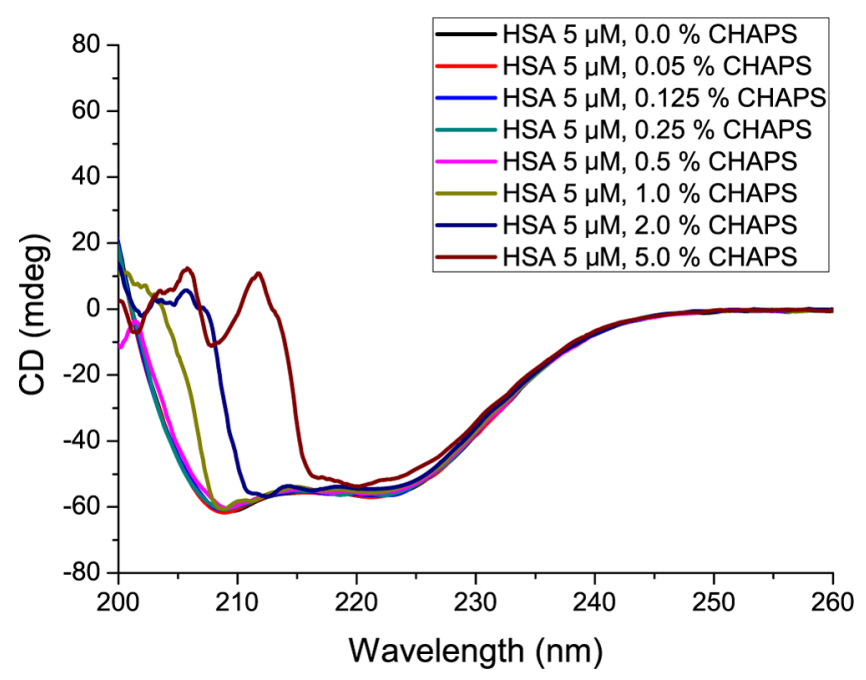

Figure 4. CD spectra of HSA $(5 \mu \mathrm{M})$ in phosphate buffer $(10 \mathrm{mM}$, $\left.\mathrm{pH} 7.4,10 \% \mathrm{D}_{2} \mathrm{O}\right)$ in the absence and presence of increasing $\%$ CHAPS.

noncovalent complex formed between the structurally analogous $\mathrm{Zr}$-Keggin POM and HEWL. The single crystal X-ray structure of the complex showed that the monomeric $\mathrm{Zr}$ Keggin POM was exclusively present in the co-crystal with the protein, giving the first full structural evidence for the existence of the catalytically active form. ${ }^{48}$ Furthermore, the structural model showed that the POM initially binds to positively charged patches on the surface of the protein. The interaction types vary from water-mediated hydrogen bonds to direct electrostatic interactions, but overall, the interaction seems to be directed by the electrostatic attraction between the negatively charged POM ligand and the positively charged amino acid side chains. ${ }^{48}$

To study the influence of increasing CHAPS concentrations on solution speciation of the POMs, ${ }^{31} \mathrm{P}$ NMR spectroscopy was further applied (see Figure S6). In the absence of CHAPS, $\mathbf{1}$ is present as the dimeric species (Zr1-WD2), whereas upon an increase in \% CHAPS, a gradual conversion takes place, in which 1 partially transforms into $\alpha_{2}-\mathrm{P}_{2} \mathrm{~W}_{17}$. As $\alpha_{2}-\mathrm{P}_{2} \mathrm{~W}_{17}$ is hydrolytically inactive, this conversion could explain the gradual decrease in reactivity observed upon an increase in \% CHAPS. In addition, ${ }^{31} \mathrm{P}$ NMR measurements were taken to understand the interaction behavior between $\mathbf{1}$ and HSA in the presence of 0.5\% CHAPS (see Figure S7). The dimeric species of 1 (Zr1WD2) is predominantly present in solution in the absence of HSA. However, upon increasing concentrations of HSA, a gradual disappearance of the signal corresponding to $\mathbf{1}$ is observed. This clearly demonstrates that in the presence of 0.5\% CHAPS, 1 interacts with HSA to form a POM/HSA complex with a longer correlation time and consequently a faster T2 relaxation. ${ }^{49}$

Tryptophan (Trp) fluorescence quenching is a powerful tool to study binding of different molecules to a protein, and it was further used to study the interaction between $\mathbf{1}$ and HSA in the presence of CHAPS. HSA contains only one Trp residue at position Trp-214, and the overall protein emission is dominated by this residue, which absorbs at the longest wavelength and displays the largest extinction coefficient. Energy absorbed by phenylalanine (Phe) and Tyr residues is often efficiently transferred to the Trp residues in the same protein. ${ }^{50}$ In a first step, the effect of the CHAPS on the Trp 
fluorescence of HSA was investigated (see Figure S8). In these steady-state fluorescence experiments, the concentration of HSA was kept constant, whereas the concentration of CHAPS was increased from 0 to $5 \% \mathrm{w} / \mathrm{v}$. Interestingly, it was found that the emission wavelength at the maximum intensity decreased from 342 to $328 \mathrm{~nm}$ as a result of the added CHAPS. The more hydrophobic environment, which is created by the addition of CHAPS, results in the shift in the emission maximum to lower wavelengths. $^{50}$

Subsequently, the effect of the presence of $0.5 \% \mathrm{w} / \mathrm{v}$ CHAPS on the quenching of the Trp fluorescence of HSA by 1 was examined (see Figure 5). The concentrations of HSA and

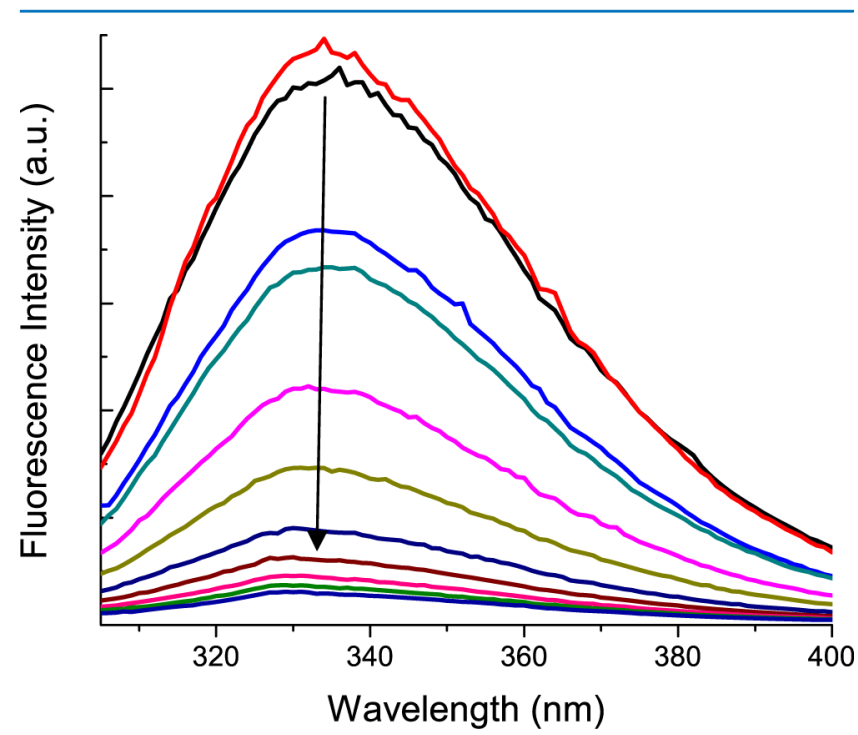

Figure 5. Emission fluorescence spectra of HSA in the presence of different concentrations of Zr1-WD2 ([HSA $]=10^{-5} \mathrm{M}$, [CHAPS $]=$ $0.5 \mathrm{wt} \%, \mathrm{pH}=7.4$ ). From top to bottom, the concentration of $\mathrm{Zr1}$ WD2 was increased stepwise from 0 to $10^{-5} \mathrm{M}$ with increments of $10^{-6} \mathrm{M}$.

CHAPS were kept constant, whereas the concentration of $\mathbf{1}$ was increased stepwise. ${ }^{51}$ Effective quenching of Trp fluorescence by $\mathbf{1}$ was observed in the presence of CHAPS, indicating that the presence of the surfactant does not hinder $\mathrm{POM} /$ protein interactions. Analysis of the data by the Tachiya model (see Experimental Section and Figure S10) revealed that quenching of $\operatorname{Trp}$ fluorescence was a result of the binding of multiple Zr1-WD2 molecules to HSA. ${ }^{52}$ Although the value of the quenching constant $\left(K_{\mathrm{q}}\right)$ of Trp by 1 in the presence of the surfactant is slightly lower $\left(3.0 \times 10^{5} \mathrm{M}^{-1}\right)$ than the $K_{\mathrm{q}}$ in the absence of the surfactant $\left(5.1 \times 10^{5} \mathrm{M}^{-1}\right)$, the model revealed that more POM was bound per HSA unit when the surfactant was present (Table S2). This is in accordance with the more "open" 3D structure of the protein caused by the surfactant, making the interaction sites more accessible for POM binding.

\section{CONCLUSIONS}

In conclusion, in this study, we have demonstrated that a metalsubstituted POM, $\mathrm{K}_{15} \mathrm{H}\left[\mathrm{Zr}\left(\alpha_{2}-\mathrm{P}_{2} \mathrm{~W}_{17} \mathrm{O}_{61}\right)_{2}\right]$ (1), selectively hydrolyzes a relatively large protein, HSA, in the presence of a zwitterionic surfactant, CHAPS, under physiological $\mathrm{pH}$ conditions. The POM catalyst preserves its hydrolytic activity in the presence of surfactant concentrations well above those that are typically used for solubilizing hydrophobic proteins. Most importantly, in the presence of the surfactant, $\mathbf{1}$ acts as a site-selective agent, hydrolyzing HSA exclusively at peptide bonds containing amino acid residues that contain carboxyl groups in their side chain. The hydrolyzed Asp and Glu peptide bonds are either located in the positive patches of the protein or contain positively charged amino acids such as Lys and His, which aid electrostatic interaction with the negatively charged POM surface. Interestingly, this study revealed that by partially unfolding the 3D structure of proteins, surfactants can be used as a means to tune the selectivity of hydrolysis by making the potential cleavage sites more accessible to the POM catalyst. We are currently investigating the hydrolysis of water-insoluble proteins in surfactant solutions. These findings may be an important step forward in developing $\mathrm{Zr}$-substituted POMs as a potential class of metalloproteases for the hydrolysis of hydrophobic and membrane proteins.

\section{EXPERIMENTAL SECTION}

Chemicals. $\alpha-/ \beta-\mathrm{K}_{6} \mathrm{P}_{2} \mathrm{~W}_{18} \mathrm{O}_{62} \cdot 14 / 19 \mathrm{H}_{2} \mathrm{O},{ }^{53} \alpha_{2}$ $\mathrm{K}_{10} \mathrm{P}_{2} \mathrm{~W}_{17} \mathrm{O}_{61} \cdot 20 \mathrm{H}_{2} \mathrm{O},{ }^{53}$ and $\mathrm{K}_{15} \mathrm{H}\left[\mathrm{Zr}-\left(\alpha_{2}-\mathrm{P}_{2} \mathrm{~W}_{17} \mathrm{O}_{61}\right)_{2}\right]$. $25 \mathrm{H}_{2} \mathrm{O}^{54}$ were prepared according to published procedures. HSA was purchased from Sigma-Aldrich in the highest available purity $(\geq 99 \%)$ and was used without further purification.

Hydrolysis Study. Solutions containing HSA (0.02 mM) and $\mathrm{K}_{15} \mathrm{H}\left[\mathrm{Zr}-\left(\alpha_{2}-\mathrm{P}_{2} \mathrm{~W}_{17} \mathrm{O}_{61}\right)_{2}\right] \cdot 25 \mathrm{H}_{2} \mathrm{O}(1 \mathrm{mM})$ with different $\% \mathrm{w} / \mathrm{v}$ of CHAPS $(0-10 \% \mathrm{w} / \mathrm{v})$ were prepared in phosphate buffer $(10 \mathrm{mM}, \mathrm{pH} 7.4)$. Samples were incubated at $60{ }^{\circ} \mathrm{C}$, and aliquots were taken at different time increments and analyzed by SDS-PAGE.

Electrophoresis. SDS-PAGE was performed on a 16\% (w/ v) polyacrylamide resolving gel (Tris- $\mathrm{HCl}$ buffer, $1.5 \mathrm{M}, \mathrm{pH}$ $8.8)$ and a $4 \%(\mathrm{w} / \mathrm{v})$ polyacrylamide stacking gel (Tris- $\mathrm{HCl}$, $0.5 \mathrm{M}, \mathrm{pH}$ 6.8). Each sample $(15 \mu \mathrm{L})$ was mixed with the sample buffer $(5 \mu \mathrm{L})$ and heated to $95{ }^{\circ} \mathrm{C}$ for $5 \mathrm{~min}$. A total of $10 \mu \mathrm{L}$ of the resulting solution was loaded onto the gel. A PageRuler prestained protein ladder $(10-170 \mathrm{kDa})$ was used as a molecular mass standard. An OmniPAGE electrophoretic cell was used with an EV243 power supply (both produced by Consort). Two SDS-PAGE gels were run at the same time in a Tris-Glycine-SDS running buffer with the maximum voltage set to $200 \mathrm{~V}$, a constant current set to $70 \mathrm{~mA}$, and the maximum power set to $50 \mathrm{~W}$. The total running time was approximately $1.5 \mathrm{~h}$. SDS-PAGE gels were visualized with silver staining, and an image of each gel was taken using a GelDoc EZ Imager (BioRad).

Edman Degradation. SDS-PAGE gels were blotted onto a PVDF membrane (using a BioRad Trans-Blot Turbo RTA Transfer Kit) and stained with Coomassie blue. Coomassiestained protein bands were cut from the membrane, destained in methanol, and washed with ultrapure water to remove any remaining salts before Edman degradation on a capillary Procise 491cLC protein sequencer (Applied Biosystems). ${ }^{55}$

${ }^{31} \mathrm{P}$ NMR Spectroscopy. To study the stability of the $\mathrm{Zr}$ POM with increasing \% of the surfactant, solutions containing $\mathrm{K}_{15} \mathrm{H}\left[\mathrm{Zr}-\left(\alpha_{2}-\mathrm{P}_{2} \mathrm{~W}_{17} \mathrm{O}_{61}\right)_{2}\right] \cdot 25 \mathrm{H}_{2} \mathrm{O}(1 \mathrm{mM})$ and increasing \% $\mathrm{w} / \mathrm{v}$ of CHAPS $(0-2 \%)$ in phosphate buffer $(10 \mathrm{mM}, \mathrm{pH} 7.4$, $\left.10 \% \mathrm{D}_{2} \mathrm{O}\right)$ were prepared. To study the effect of increasing concentrations of HSA on the stability of $\mathrm{Zr}-\mathrm{POM}$ in the presence of a specific $\mathrm{w} / \mathrm{v} \%$ of the surfactant, solutions containing $\mathrm{K}_{15} \mathrm{H}\left[\mathrm{Zr}-\left(\alpha_{2}-\mathrm{P}_{2} \mathrm{~W}_{17} \mathrm{O}_{61}\right)_{2}\right] \cdot 25 \mathrm{H}_{2} \mathrm{O} \quad(2 \mathrm{mM})$ and HSA $(0,0.2,0.4$, or $0.5 \mathrm{mM})$ in a certain $\mathrm{w} / \mathrm{v} \%$ of the surfactant $(0.5 \%$ CHAPS) in phosphate buffer $(10 \mathrm{mM}, \mathrm{pH}$ 7.4) were also prepared. ${ }^{31} \mathrm{P}$ NMR spectra of the different 
samples were recorded after mixing and after incubation at 60 ${ }^{\circ} \mathrm{C}$ at different time increments by using a Bruker Avance 400 $\mathrm{MHz}$ spectrometer. As an external standard, $25 \% \mathrm{H}_{3} \mathrm{PO}_{4}$ in $\mathrm{D}_{2} \mathrm{O}$ in a sealed capillary was used.

CD Spectroscopy. To study the effect of increasing \% of the surfactant on the secondary structure of HSA, solutions containing HSA $(5 \mu \mathrm{M})$ and increasing $\% \mathrm{w} / \mathrm{v}$ of CHAPS (0$5 \%)$ in phosphate buffer $(10 \mathrm{mM}, \mathrm{pH} 7.4)$ were prepared. To study the effect of increasing concentrations of $\mathrm{Zr}$-POM on the secondary structure of HSA in the presence of a specific \% surfactant, solutions containing HSA $(5 \mathrm{uM})$ and $\mathrm{K}_{15} \mathrm{H}\left[\mathrm{Zr}-\left(\alpha_{2}-\right.\right.$ $\left.\left.\mathrm{P}_{2} \mathrm{~W}_{17} \mathrm{O}_{61}\right)_{2}\right] \cdot 25 \mathrm{H}_{2} \mathrm{O}(0-25 \mu \mathrm{M})$ in a certain \% surfactant (0.5\% CHAPS) in phosphate buffer $(10 \mathrm{mM}, \mathrm{pH} 7.4)$ were also prepared. CD measurements were performed at RT using a Jasco J-1500 spectropolarimeter, and each sample was separately measured in a quartz cell with an optical path length of $1 \mathrm{~mm}$. Scans were recorded in the far-UV wavelength region $(\lambda=200-260 \mathrm{~nm})$, where peptide bond absorption takes place. For each CD measurement, a baseline correction was performed by subtracting the spectrum of the respective buffer solution with its specific \% surfactant from the spectrum of the protein.

Fluorescence Spectroscopy. Steady-state fluorescence experiments were recorded on a Photon Technology Quanta Master QM-6/2005 spectrofluorimeter. Quartz cuvettes with a $10.0 \mathrm{~mm}$ optical path length were used. Spectra were recorded in a buffered $10 \mu \mathrm{M}$ protein concentration solution (phosphate buffer, $\mathrm{pH}=7.4$ ) at room temperature monitoring the emission from 305 to 400 or $420 \mathrm{~nm}$, with a maximum at approximately $330 \mathrm{~nm}$. Excitation of the sample took place at $295 \mathrm{~nm}$ to avoid excitation of tyrosine residues. The emission and excitation slit widths were opened at $0.37 \mathrm{~mm}$ (resolution of $1.0 \mathrm{~nm}$ ). The following concentrations of the used surfactants in the absence of POM were measured: $0,0.2,0.5,1.0,2.0$, and $5.0 \% \mathrm{w} / \mathrm{v}$. The Zr1-WD2 POM concentration was increased stepwise from 0 to $10 \mu \mathrm{M}$ with increments of $1.0 \mu \mathrm{M}$ and in the presence of $0.5 \% \mathrm{w} / \mathrm{v}$ of surfactant. The analysis of the results for the $\mathrm{Zr} 1$ WD2 POM in the presence of SDS was carried out with the help of a derived Stern-Volmer equation ${ }^{56}$

$$
\log \left[\frac{F_{0}-F}{F}\right]=\log K_{\mathrm{q}}+n \log [\mathrm{Q}]
$$

where $F_{0}$ is the unquenched fluorescence intensity, $F$ the fluorescence in the presence of the quencher, and [Q] the concentration of the quencher.

The fluorescence data of the Zr1-WD2 POM in the presence of CHAPS were analyzed using a different equation because we expect the number of bound molecules to be higher than 1. For this reason, the Tachiya model, ${ }^{52}$ eq 2 , is used

$$
\log \left[\frac{F_{0}-F}{F}\right]=m \log K_{\mathrm{q}}+m \log \left([\mathrm{Q}]-[\mathrm{M}] \frac{F_{0}-F}{F}\right)
$$

where $F_{0}$ is the unquenched fluorescence intensity, $F$ the fluorescence in the presence of the quencher, $[\mathrm{Q}]$ the concentration of the quencher, $[\mathrm{M}]$ the concentration of the protein, and $m$ the number of binding sites.

\section{ASSOCIATED CONTENT}

\section{S Supporting Information}

The Supporting Information is available free of charge on the ACS Publications website at DOI: 10.1021/acsomega.7b00168.
Experimental section, SDS-PAGE gels, Edman degradation results, CD spectra, ${ }^{31} \mathrm{P}$ NMR spectra, fluorescence spectra, references (PDF)

\section{AUTHOR INFORMATION}

\section{Corresponding Author}

*E-mail: tatjana.vogt@chem.kuleuven.be.

ORCID $\odot$

Tatjana N. Parac-Vogt: 0000-0002-6188-3957

Notes

The authors declare no competing financial interest.

\section{ACKNOWLEDGMENTS}

A.S. and L.V. acknowledge FWO Flanders (Belgium) for a doctoral fellowship. V.G. thanks KU Leuven for a doctoral fellowship. T.N.P.-V. and P.P. thank FWO Flanders and KU Leuven for financial support.

\section{ABBREVIATIONS}

POM, polyoxometalate; CHAPS, 3-[(3-cholamidopropyl)dimethylammonio]-1-propanesulfonate; HSA, human serum albumin; HEWL, hen egg white lysozyme; CD, circular dichroism; SDS-PAGE, sodium dodecyl sulfate polyacrylamide gel electrophoresis; DOSY, Diffusion Ordered NMR Spectroscopy; CMC, critical micelle concentration

\section{REFERENCES}

(1) Santoni, V.; Molloy, M.; Rabilloud, T. Membrane proteins and proteomics: un amour impossible? Electrophoresis 2000, 21, 10541070.

(2) Wallin, E.; von Heijne, G. Genome-wide analysis of integral membrane proteins from eubacterial, archaean, and eukaryotic organisms. Protein Sci. 1998, 7, 1029-1038.

(3) Overington, J. P.; Al-Lazikani, B.; Hopkins, A. L. How many drug targets are there? Nat. Rev. Drug Discovery 2006, 5, 993-996.

(4) Westermeier, R.; Naven, T. Proteomics in Practice: A Laboratory Manual of Proteome Analysis, 3rd ed.; Wiley-VCH Verlag-GmbH: Weinheim, 2002.

(5) Radzicka, A.; Wolfenden, R. Rates of Uncatalyzed Peptide Bond Hydrolysis in Neutral Solution and the Transition State Affinities of Proteases. J. Am. Chem. Soc. 1996, 118, 6105-6109.

(6) Smith, R. M.; Hansen, D. E. The pH-Rate Profile for the Hydrolysis of a Peptide Bond. J. Am. Chem. Soc. 1998, 120, 89108913.

(7) Bryant, R. A. R.; Hansen, D. E. Direct Measurement of the Uncatalyzed Rate of Hydrolysis of a Peptide Bond. J. Am. Chem. Soc. 1996, 118, 5498-5499.

(8) Privé, G. G. Detergents for the stabilization and crystallization of membrane proteins. Methods 2007, 41, 388-397.

(9) Miskevich, F.; Davis, A.; Leeprapaiwong, P.; Giganti, V.; Kostic, N. M.; Angel, L. A. Metal complexes as artificial proteases in proteomics: A palladium(II) complex cleaves various proteins in solutions containing detergents. J. Inorg. Biochem. 2011, 105, 675-683.

(10) Wezynfeld, N. E.; Frączyk, T.; Bal, W. Metal assisted peptide bond hydrolysis: Chemistry, biotechnology and toxicological implications. Coord. Chem. Rev. 2016, 327-328, 166-187.

(11) Zhu, L.; Bakhtiar, R.; Kostic, N. M. Transition-metal complexes as alternatives to proteolytic enzymes. Regioselective cleavage of myoglobin by palladium(II) aqua complexes. J. Biol. Inorg. Chem. 1998, 3, 383-391.

(12) Dutca, L. M.; Ko, K. S.; Pohl, N. L.; Kostic, N. M. Platinum(II) Complex as an Artificial Peptidase: Selective Cleavage of Peptides and a Protein by cis- $[\mathrm{Pt}(\mathrm{en})(\mathrm{H} 2 \mathrm{O}) 2] 2$ + Ion under Ultraviolet and Microwave Irradiation. Inorg. Chem. 2005, 44, 5141-5146. 
(13) Hegg, E. L.; Burstyn, J. N. Hydrolysis of Unactivated Peptide Bonds by a Macrocyclic Copper(II) Complex: $\mathrm{Cu}([9] \mathrm{aneN} 3) \mathrm{Cl} 2$ Hydrolyzes Both Dipeptides and Proteins. J. Am. Chem. Soc. 1995, 117, 7015-7016.

(14) Milović, N. M.; Dutca, L. M.; Kostic, N. M. Combined Use of Platinum(II) Complexes and Palladium(II) Complexes for Selective Cleavage of Peptides and Proteins. Inorg. Chem. 2003, 42, 4036-4045.

(15) Zhu, L. G.; Qin, L.; Parac, T. N.; Kostic, N. M. Site-Specific Hydrolytic Cleavage of Cytochrome $\mathrm{c}$ and of Its Heme Undecapeptide, Promoted by Coordination Complexes of Palladium(II). J. Am. Chem. Soc. 1994, 116, 5218-5224.

(16) Milović, N. M.; Dutca, L. M.; Kostic, N. M. Transition-Metal Complexes as Enzyme-Like Reagents for Protein Cleavage: Complex cis- $[\mathrm{Pt}(\mathrm{en})(\mathrm{H} 2 \mathrm{O}) 2] 2+$ as a New Methionine-Specific Protease. Chem. - Eur. J. 2003, 9, 5097-5106.

(17) Kopera, E.; Belczyk-Ciesielska, A.; Bal, W. Application of Ni(II)Assisted Peptide Bond Hydrolysis to Non-Enzymatic Affinity Tag Removal. PLoS One 2012, 7, No. e36350.

(18) Proust, A.; Thouvenot, R.; Gouzerh, P. Functionalization of polyoxometalates: towards advanced applications in catalysis and materials science. Chem. Commun. 2008, 16, 1837-1852.

(19) Long, D.-L.; Tsunashima, R.; Cronin, L. Polyoxometalates: Building Blocks for Functional Nanoscale Systems. Angew. Chem., Int. Ed. 2010, 49, 1736-1758.

(20) Long, D.-L.; Burkholder, E.; Cronin, L. Polyoxometalate clusters, nanostructures and materials: From self assembly to designer materials and devices. Chem. Soc. Rev. 2007, 36, 105-121.

(21) Kholdeeva, O. A.; Maksimov, G. M.; Maksimovskaya, R. I.; Vanina, M. P.; Trubitsina, T. A.; Naumov, D. Y.; Kolesov, B. A.; Antonova, N. S.; Carbo, J. J.; Poblet, J. M. ZrIV-Monosubstituted Keggin-Type Dimeric Polyoxometalates: Synthesis, Characterization, Catalysis of H2O2-Based Oxidations, and Theoretical Study. Inorg. Chem. 2006, 45, 7224-7234.

(22) Al-Kadamany, G.; Mal, S. S.; Milev, B.; Donoeva, B. G.; Maksimovskaya, R. I.; Kholdeeva, O. A.; Kortz, U. Hexazirconium- and Hexahafnium-Containing Tungstoarsenates(III) and Their Oxidation Catalysis Properties. Chem. - Eur. J. 2010, 16, 11797-11800.

(23) Dupré, N.; Remy, P.; Micoine, K.; Boglio, C.; Thorimbert, S.; Lacote, E.; Hasenknopf, B.; Malacria, M. Chemoselective Catalysis with Organosoluble Lewis Acidic Polyoxotungstates. Chem. - Eur. J. 2010, 16, 7256-7264.

(24) Carraro, M.; Nsouli, N.; Oelrich, H.; Sartorel, A.; Soraru, A.; Mal, S. S.; Scorrano, G.; Walder, L.; Kortz, U.; Bonchio, M. Reactive ZrIV and HfIV Butterfly Peroxides on Polyoxometalate Surfaces: Bridging the Gap between Homogeneous and Heterogeneous Catalysis. Chem. - Eur. J. 2011, 17, 8371-8378.

(25) Rhule, J. T.; Hill, C. L.; Judd, D. A.; Schinazi, R. F. Polyoxometalates in Medicine. Chem. Rev. 1998, 98, 327-358.

(26) Flütsch, A.; Schroeder, T.; Gruetter, M. G.; Patzke, G. R. HIV-1 protease inhibition potential of functionalized polyoxometalates. Bioorg. Med. Chem. Lett. 2011, 21, 1162-1166.

(27) Yanagie, H.; Ogata, A.; Mitsui, S.; Hisa, T.; Yamase, T.; Eriguchi, M. Anticancer activity of polyoxomolybdate. Biomed. Pharmacother. 2006, 60, 349-352.

(28) Ogata, A.; Mitsui, S.; Yanagie, H.; Kasano, H.; Hisa, T.; Yamase, T.; Eriguchi, M. A novel anti-tumor agent, polyoxomolybdate induces apoptotic cell death in AsPC-1 human pancreatic cancer cells. Biomed. Pharmacother. 2005, 59, 240-244.

(29) Ho, P. H.; Breynaert, E.; Kirschhock, C. E. A.; Parac-Vogt, T. N. Hydrolysis of carboxyesters promoted by vanadium(V) oxyanions. Dalton Trans. 2011, 40, 295-300.

(30) Absillis, G.; Cartuyvels, E.; Van Deun, R.; Parac-Vogt, T. N. Hydrolytic Cleavage of an RNA-Model Phosphodiester Catalyzed by a Highly Negatively Charged Polyoxomolybdate [Mo7O24]6- Cluster. J. Am. Chem. Soc. 2008, 130, 17400-17408.

(31) Steens, N.; Ramadan, A. M.; Absillis, G.; Parac-Vogt, T. N. Hydrolytic cleavage of DNA-model substrates promoted by polyoxovanadates. Dalton Trans. 2010, 39, 585-592.
(32) Phuong Hien, H.; Stroobants, K.; Parac-Vogt, T. N. Hydrolysis of Serine-Containing Peptides at Neutral pH Promoted by [MoO4]2Oxyanion. Inorg. Chem. 2011, 50, 12025-12033.

(33) Cartuyvels, E.; Absillis, G.; Parac-Vogt, T. N. Questioning the paradigm of metal complex promoted phosphodiester hydrolysis: [Mo7O24]6- polyoxometalate cluster as an unlikely catalyst for the hydrolysis of a DNA model substrate. Chem. Commun. 2008, 85-87.

(34) Stroobants, K.; Phuong Hien, H.; Moelants, E.; Proost, P.; Parac-Vogt, T. N. Selective hydrolysis of hen egg white lysozyme at Asp-X peptide bonds promoted by oxomolybdate. J. Inorg. Biochem. 2014, 136, 73-80.

(35) Sap, A.; Absillis, G.; Parac-Vogt, T. N. Selective Hydrolysis of Oxidized Insulin Chain B by a $\mathrm{Zr}$ (IV)-Substituted Wells-Dawson Polyoxometalate. Dalton Trans. 2015, 44, 1539-1548.

(36) Stroobants, K.; Moelants, E.; Ly, H. G. T.; Proost, P.; Bartik, K.; Parac-Vogt, T. N. Polyoxometalates as a Novel Class of Artificial Proteases: Selective Hydrolysis of Lysozyme under Physiological $\mathrm{pH}$ and Temperature Promoted by a Cerium(IV) Keggin-Type Polyoxometalate. Chem. - Eur. J. 2013, 19, 2848-2858.

(37) Stroobants, K.; Absillis, G.; Moelants, E.; Proost, P.; Parac-Vogt, T. Regioselective Hydrolysis of Human Serum Albumin by ZrIVSubstituted Polyoxotungstates at the Interface of Positively Charged Protein Surface Patches and Negatively Charged Amino Acid Residues. Chem. - Eur. J. 2014, 20, 3894-3897.

(38) Stroobants, K.; Goovaerts, V.; Absillis, G.; Bruylants, G.; Moelants, E.; Proost, P.; Parac-Vogt, T. N. Molecular Origin of the Hydrolytic Activity and Fixed Regioselectivity of a ZrIV-Substituted Polyoxotungstate as Artificial Protease. Chem. - Eur. J. 2014, 20, 9567-9577.

(39) Ly, H. G. T.; Absillis, G.; Janssens, R.; Proost, P.; Parac-Vogt, T. N. Highly Amino Acid Selective Hydrolysis of Myoglobin at Aspartate Residues as Promoted by Zirconium(IV)-Substituted Polyoxometalates. Angew. Chem., Int. Ed. 2015, 54, 7391-7394.

(40) Sap, A.; van Tichelen, L.; Mortier, A.; Proost, P.; Parac-Vogt, T. $\mathrm{N}$. Tuning the selectivity and reactivity of metal-substituted polyoxometalates as artificial proteases by varying the nature of the imbedded Lewis-acid metal ion. Eur. J. Inorg. Chem. 2016, 2016, $5098-5105$.

(41) Quanten, T.; Shestakova, P.; Van Den Bulck, D.; Kirschhock, C.; Parac-Vogt, T. N. Interaction Study and Reactivity of ZrIVSubstituted Wells-Dawson Polyoxometalate towards Hydrolysis of Peptide Bonds in Surfactant Solutions. Chem. - Eur. J. 2016, 22, 3775-3784.

(42) Kurth, D. G.; Lehmann, P.; Volkmer, D.; Colfen, H.; Koop, M. J.; Muller, A.; Du Chesne, A. Surfactant-Encapsulated Clusters (SECs): (DODA)20(NH4)[H3Mo57V6(NO)6O183(H2O)18], a Case Study. Chem. - Eur. J. 2000, 6, 385-393.

(43) Stephan, H.; Kubeil, M.; Emmerling, F.; Mueller, C. E. Polyoxometalates as Versatile Enzyme Inhibitors. Eur. J. Inorg. Chem. 2013, 2013, 1585-1594.

(44) Hjelmeland, L. M. A nondenaturing zwitterionic detergent for membrane biochemistry: design and synthesis. Proc. Natl. Acad. Sci. U.S.A. 1980, 77, 6368-6370.

(45) Stark, R. E.; Leff, P. D.; Milheim, S. G.; Kropf, A. Physical studies of CHAPS, a new detergent for the study of visual pigments. $J$. Phys. Chem. 1984, 88, 6063-6067.

(46) Oliyai, C.; Borchardt, R. T. Chemical Pathways of Peptide Degradation. IV. Pathways, Kinetics, and Mechanism of Degradation of an Aspartyl Residue in a Model Hexapeptide. Pharm. Res. 1993, 10, 95-102.

(47) Johnson, M. Detergents: Triton X-100, Tween-20, and More. Mater. Methods 2013, 3, 163-175.

(48) Sap, A.; De Zitter, E.; Van Meervelt, L.; Parac-Vogt, T. N. Structural Characterization of the Complex between Hen Egg-White Lysozyme and ZrIV-Substituted Keggin Polyoxometalate as Artificial Protease. Chem. - Eur. J. 2015, 21, 11692-11695.

(49) Zerbe, O. Methods and Principals in Medicinal Chemistry; Mannhold, R.; Folkers, G., et al., Eds.; Wiley VCH: Weinheim, 2003; Vol. 16. 
(50) Lakowicz, J. R. Principles of Fluorescence Spectroscopy, 3rd ed.; Springer US: New York, 2006.

(51) Goovaerts, V.; Stroobants, K.; Absillis, G.; Parac-Vogt, T. Understanding the Regioselective Hydrolysis of Human Serum Albumin by $\mathrm{Zr}(\mathrm{IV})$-Substituted Polyoxotungstates Using Tryptophan Fluorescence Spectroscopy. Inorganics 2015, 3, 230-245.

(52) Xiao, J. B.; Chen, X. Q.; Jiang, X. Y.; Hilczer, M.; Tachiya, M. Probing the Interaction of Trans-resveratrol with Bovine Serum Albumin: A Fluorescence Quenching Study with Tachiya Model. J. Fluoresc. 2008, 18, 671

(53) Contant, R.; Klemperer, W. G.; Yaghi, O. Inorganic Syntheses; Ginsberg, A. P., Ed.; John Wiley \& Sons: New York, 1990; Vol. 27.

(54) Kato, C. N.; Shinohara, A.; Hayashi, K.; Nomiya, K. Syntheses and X-ray Crystal Structures of Zirconium(IV) and Hafnium(IV) Complexes Containing Monovacant Wells-Dawson and Keggin Polyoxotungstates. Inorg. Chem. 2006, 45, 8108-8119.

(55) Loos, T.; Mortier, A.; Proost, P. In Methods in Enzymology, Vol 461: Chemokines, Part B, Vol. 461; Handel, T. M., Hamel, D. J., Eds., 2009, pp 3-29.

(56) Hungerford, G.; Hussain, F.; Patzke, G. R.; Green, M. The photophysics of europium and terbium polyoxometalates and their interaction with serum albumin: a time-resolved luminescence study. Phys. Chem. Chem. Phys. 2010, 12, 7266-7275. 